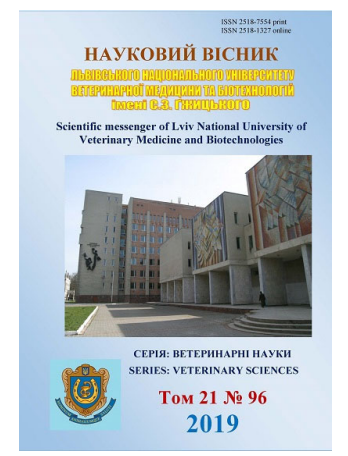

\author{
Науковий вісник Львівського національного університету \\ ветеринарної медицини та біотехнологій імені С.3. Гжицького. \\ Серія: Ветеринарні науки
}

\title{
The association of cryptocotylosis with other types of parasitic invasions of gobiidae fishes in the natural waters of southern Ukraine
}

\author{
S.L. Honcharov
}

National University of Life and Environmental Sciences of Ukraine, Kyiv, Ukraine

Article info

Received 04.10.2019

Received in revised form 13.11.2019

Accepted 14.11.2019

National University of Life and Environmental Sciences of Ukraine, Polkovnyka

Potekhina Str., 16, Kyiv, 03041, Ukraine.

Tel.:+38-097-902-26-85

E-mail:sergeyvet85@ukr.net
Honcharov, S.L. (2019). The association of cryptocotylosis with other types of parasitic invasions of gobiidae fishes in the natural waters of southern Ukraine. Scientific Messenger of Lviv National University of Veterinary Medicine and Biotechnologies. Series: Veterinary sciences, 21(96), 101107. doi: $10.32718 /$ nvlvet 9618

The article gives the result of the research of such fishes of the Gobiidae bloodline as Neogobius fluviatialis Pallas, 1814, Neogobius melanostomum Pallas, 1814, and Mesogobius batrachocephalus Pallas, 1814, in the waters of the Dnipro-Buh estuary and the Black Sea near Mykolayiv and Odessa regions. It established the possible associations of cryptocotylosis with other types of parasitic invasions of Gobiidae fishes. It has been set up that the researched fishes have been the most invaded by such agents of parasitic diseases as trematodes and nematodes $-52.2 \%$ and $37.3 \%$ respectively. The smallest parasitic group affecting commercial fishes is cestodiasis - 0.37\%. Neogobius fluviatialis Pallas, 1814, has been noticed as invaded by Asymphylodora pontica Chernyshenko, 1949. The prevelence $(P)$ counted $2.58 \%$, and the invasion intensiveness (II) counted 4-12 samples. Cryptocotyle concavum Creplin, 1825 (P - 30.4\%, II - 9124 samples); Cryptocotyle jejuna Nicoll, 1907 (P - 15.9\%, II - 12-103 metacecaria); Ligula pavlovski Dubinina, 1959 (P - 0.21\%, II - 1sample); Cucullanellus minutus Rudolphi, 1819 (P - 9.05\%, II - 1-3 nematodes); Eustrongylides excisus, Jägerskiöld, 1909 (P - 23.06\%, II - 1 - 4 larvae); Raphidascaris sp. (P - 2.8\%, II - 1 nematode); Telosentis exiguus (Linstow, 1901) (P - 1.07\%, II - 1-2 samples.); Ergasilus nanus (Beneden, 1870) (IE - 8.18\%, II - 1-31 maxillopods). The parasitic fauna of Neogobius melanostomum Pallas, 1814 was characterized by such agents as Asymphylodora pontica Chernyshenko, 1949 (P 10.2\%, II - 5-36 samples); Cryptocotyle concavum Creplin, 1825 (P-59.2\%, II - 94-211 samples); Cryptocotyle jejuna Nicoll, 1907 (P - 44.8\%, II - 4-87 metacercaria); Stephanostomum bicoronatum (Stossich, 1883) Fuhrmann, 1928 (P - 26.5\%, II - 6 - 69 larvae); Ligula pavlovski Dubinina, 1959 (P - 2.04\%, II 1sample); Cucullanellus minutus Rudolphi, 1819 (P - 16.3\%, II - 1-6 nematodes); Eustrongylides excisus, Jägerskiöld, 1909 (P - 22.4\%, II - 1-4 larvae); Raphidascaris sp. (P - 4.08\%, II - 1-2 nematodes); Telosentis exiguus (Linstow, 1901) ( $P$ - 8.16\%, II - 1-2 samples); Ergasilus nanus Beneden, 1870 (P14.2\%, II - 2-8 maxillopods). Parasitic invasions of Mesogobius batrachocephalus Pallas, 1814, also took place. For example, there were registered the cases of invasion with such agents as Cryptocotyle concavum Creplin, 1825 (P - 17\%, II - 18-89 samples); Cryptocotyle jejuna Nicoll, 1907 (P - 13.5\%, II - 7-21 metacecaria); Stephanostomum bicoronatum (Stossich, 1883) Fuhrmann, 1928 (P-6.77\%, II - 5-11 larvae); Cucullanellus minutus Rudolphi, 1819 (P - 35.6\%, II - 1-3 nematodes); Eustrongylides excisus, Jägerskiöld, 1909 (P-32.2\%, II - 1-3 larvae); Contracaecum sp. (P - 5.08\%, II - I nematode); Ergasilus nanus Beneden, 1870 ( $P-8.74 \%$, II - 1-15 parasites).

Key words: cryptocotylosis, speading, association, Gobiidae fishes, mixtinvasion.

\section{Асоціація криптокотильозу з іншими паразитарними інвазіями бичкових риб природних водойм півдня України}

\author{
С.Л. Гончаров
}

Національний університет біоресурсів і природокористування Украӥни, м. Київ, Украӥна 
У даній статті подано результати дослідження бичкових видів риб (бичка-пісочника - Neogobius fluviatialis Pallas, 1814, бичка-кругляка - Neogobius melanostomum Pallas, 1814 та бичка-мартовика - Mesogobius batrachocephalus Pallas, 1814) в aкваторіяx Дніпро-Бузького лиману $і$ Чорного моря Миколаӥвської $і$ Одеської областей та встановлено можливі асоиіаиї криптокотильозної інвазї із іншими паразитозами бичків. Виявлено, щуо досліджувана риба має найбільщі показники ураження збудниками паразитарних хвороб, якими є трематоди та нематоди: 52,2 та 37,3\% відповідно. Найменшою групою паразитів, шзо уражає промислових риб є иестодози - 0,37\%. Серед бичків-пісочників виявляли ураження Asymphylodora pontica Chernyshenko, 1949 екстенсивність інвазї була (EI) 2,58\%, а інтенсивність інвазії (II) в межах 4 - 12 екз.; Cryptocotyle concavum Creplin, 1825 (EI - 30,4\%, II - 9124 екз); Cryptocotyle jejuna Nicoll, 1907 (EI - 15,9\%, II - 12-103 метаџеркаріïв); Ligula pavlovski Dubinina,1959 (EI - 0,21\%, II 1 екз.); Cucullanellus minutus Rudolphi, 1819 (EI-9,05\%, II - 1-3 немamodu); Eustrongylides excisus, Jägerskiöld, 1909 (EI - 23,06\%, II-1-4 личинок); Raphidascaris sp. (EI - 2,8\%, II - 1 нематода); Telosentis exiguus (Linstow, 1901) (EI - 1,07\%, II - 1-2 eкз.); Ergasilus nanus (Beneden, 1870) (EI - 8,18\%, II - 1-31 рачок). Паразитофауна бичка-кругляка характеризувалась збудниками Asymphylodora pontica Chernyshenko, 1949 (EI - 10,2\%, II - 5-36 екз.); Cryptocotyle concavum Creplin, 1825 (EI - 59,2\%, II - 94-211 екз); Cryptocotyle jejuna Nicoll, 1907 (EI - 44,8\%, II - 4-87 метацеркарї̈в); Stephanostomum bicoronatum (Stossich, 1883) Fuhrmann, 1928 (EI- 26,5\%, II - 6 - 69 личинок); Ligula pavlovski Dubinina, 1959 (EI - 2,04\%, II - 1 eкз.); Cucullanellus minutus Rudolphi, 1819 (EI-16,3\%, II - 1-6 нематод); Eustrongylides excisus, Jägerskiöld, 1909 (EI - 22,4\%, II - 1-4 личинок); Raphidascaris sp. (EI - 4,08\%, II - 1-2 нематодu); Telosentis exiguus (Linstow, 1901) (EI - 8,16\%, II - 1-2 екз.); Ergasilus nanus Beneden, 1870 (EI - 14,2\%, II - 2-8 рачків). Зараження бичка-мартовика збудниками паразитарних хвороб також мали місце. Так, реєстрували Сrурtосотуlе сопсауит Creplin, 1825 (EI - 17\%, II - 18-89 екз); Cryptocotyle jejuna Nicoll, 1907 (EI - 13,5\%, II - 7-21 метаuеpкapiü); Stephanostomum bicoronatum (Stossich, 1883) Fuhrmann, 1928 (EI - 6,77\%, II - 5-11 личинок); Cucullanellus minutus Rudolphi, 1819 (EI - 35,6\%, II - 1-3 нематоди); Eustrongylides excisus, Jägerskiöld, 1909 (EI - 32,2\%, II - 1-3 личинки); Contracaеcum sp. (EI - 5,08\%, II - 1 нематода); Ergasilus nanus Beneden, 1870 (EI-8,74\%, II-1-15 паразитів).

Ключові слова: криптокотильоз, поширення, асоціація, бичкові риби, мікстінвазія.

\section{Ветуп}

Паразитизм - одна із найбільш успішних форм існування організмів, про що свідчить велике видове різноманіття паразитів та значення цього явища в еволюції. Склад паразитофауни визначається комплексом зв'язків, з яких головну роль відіграють видове різноманіття i чисельність кінцевих та проміжних хазяїв. Організми, що вільно існують у навколишньому середовищі, неминуче контактують та взаємодіють iз біотичними та абіотичними факторами довколишнього середовища біотопу. Водночас взаємодія паразита із середовищем біотопу покладається на хазяїна, хоч у більшості й опосередковано (Dogel', 1962). Саме такими паразитами риб є метацеркарії родини Heterophyidae. В роді нараховується 8 видів: Cryptocotyle concava Creplin, 1825; Cryptocotyle lingua Creplin, 1825; Cryptocotyle jejuna Nicoll, 1907; Cryptocotyle badamshini Kurochkin, 1959; Cryptocotyle cryptocotyloides Issaitschikow, 1923; Cryptocotyle delamurei Jurachno, 1987; Cryptocotyle quinqueangularis Skrjabin, 1923; Cryptocotyle thapari McIntosh 1953 (Gibson et al., 2002; 2005; 2008).

Збудник криптокотильозу паразитує в кишках рибоїдних птахів, морських ссавців, собак, а також у людини (Sudarikov et al., 2006; Moshu, 2014). Проміжна стадія розвитку, метацеркарій, паразитує в тканинах риб, в основному родини Gobiidae (Malek, 2004).

Встановлено поширення даного паразита у морських та лиманних водах ряду країн: Росії, Німеччини, Болівії, Великобританії, Болгарії, Франції, Молдови, Польщі тощо (Gardner \& Thew, 2006; Thieltges et al., 2006; Rolbiecki, 2006; Martynenko, 2016). На території України зареєстровано паразитування C. јејипа у Керченському проливі у чайки Larus cachinnans Pallas, 1811. Представників цього виду раніше на зазначеній території не реєстрували (Martynenko, 2012).

Наявні літературні джерела обмежено описують біологію збудника, патогенез хвороби у риб, хоча й підтверджують факт його широкого поширення на території багатьох країн. Водночас даних щодо поширення трематоди родини Heterophyidae у риб на території України майже немає.

Метою дослідження було обстежити бичкових риб у акваторіях Дніпро-Бузького лиману і Чорного моря Миколаївської та Одеської областей і встановити можливі асоціації криптокотильозної інвазії із іншими паразитозами риб.

\section{Матеріал і методи досліджень}

Упродовж 2014-2018 років клініко-лабораторному дослідженню було піддано 572 екземпляри трьох видів бичових риб, а саме: бичка-пісочника - 464 екз., бичка-кругляка - 49 екз. та бичка-мартовика - 59 екз. Відбирали рибу під час проведення планових контрольних обловів. Відловлювали iï вудочками, а також купляли у рибалок на місці вилову. Відбір зразків риби проводили вздовж берегової лінії Чорного моря, а також у ділянці Дніпро-Бузького лиману, в адміністративних межах Миколаївської області (мис Аджігол, місто Очаків, село Рибаківка Березанського району) та у частині акваторії Чорного моря, що адміністративно розташоване в Одеській області (місто Южний, місто Одеса, місто Чорноморськ).

Іхтіопатологічному дослідженню піддавали всі види бичкових риб Mesogobius batrachocephalus Pallas, 1814, Neogobius melanostomum Pallas, 1814, Neogobius fluviatialis Pallas, 1814. Клінічне дослідження проводили шляхом уважного огляду поверхні луски та шкірних покривів. Окремо досліджували ротову та зяброву порожнини. Розтинали черевну порожнину розрізом, який починали від анального отвору та спрямовували до голови. Препарували та відокремлювали кожен орган. Окремо відділяли і досліджували кишечник та його вміст. Для дослідження м'язової тканини попередньо знімали шкіру. Виділяли та досліджували головний та спинний мозок, а також кришталик ока (Bikhovskaya-Pavlovskaya, 1985). Виявлених паразитів 
поміщали в чашку Петрі, за необхідності фарбували та готували постійні препарати і досліджували за допомогою мікроскопа стереоскопічного Micromed XS-6320. Морфологічні характеристики паразитів вивчали за визначником Bauer (1987) та Keys to the Trematoda (Gibson et al., 2002; 2005; 2008).

Визначали екстенсивність та інтенсивність інвазії у досліджуваних риб. Отриману цифрову інформацію обробляли статистично та визначали середні арифметичні величини.

\section{Результати та їх обговорення}

При проведенні іхтіопатологічного дослідження бичка-пісочника було встановлено, що зазначений вид риб уражений трематодою $A$. pontica. Показник екстенсивності інвазії становив 2,58\%, а показники

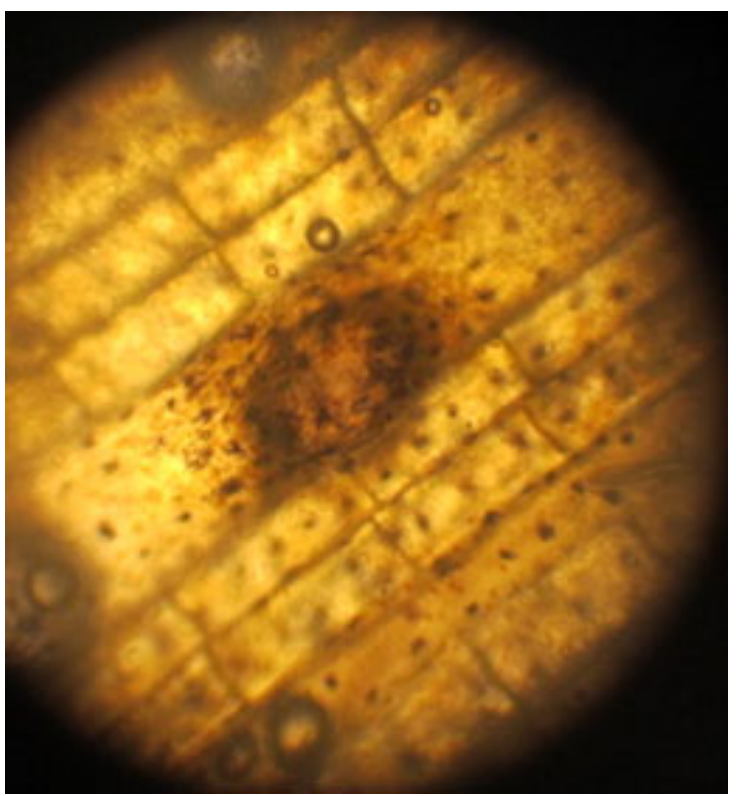

Рис. 1. Метацеркарій C. сопсаvит на поверхні плавця бичка-пісочника (збільш. х 80)

Варто відзначити цікаву знахідку у бичків N. fluviatialis, - плероцеркоїди цестоди L. pavlovski. Дана знахідка була одиничною. Кількість виявлених паразитів також була в межах одного екземпляра. Такі знахідки в більшості $є$ випадковістю, аніж закономірністю, що свідчить про використання в раціоні бичків-пісочників циклопів та діаптомусів. За результатами клініко-лабораторних досліджень було встановлено інвазування бичка-пісочника нематодою C. minutus. Кількість уражених риб цим збудником була в межах 9,05\%, а амплітуда інтенсивності інвазії склала 1-3 нематоди. Варто сказати окремо про личинок Raphidascaris sp., яких було виявлено у порожнині тіла бичків, а також під капсулою гепатопанкреаса та в його паренхімі. Показники ураження складали 2,8\% від загальної кількості досліджених бичків цього виду. Інтенсивність інвазії була в межах одного екземпляра. Цікаво відмітити той факт, що знахідки личинок нематод Raphidascaris sp. знайдено лише у бичків, що були виловлені в умовах солонуватих водойм амплітуди інтенсивності інвазії були в межах 4-12 паразитів. Значні показників інвазування відмічали при ураженні метацеркаріями трематоди родини Heterophyidae: $C$. cancavum i $C$. јејипа. Екстенсивність інвазії за ураження метацеркаріями $C$. cancavum складала $-30,4 \%$, а межі інтенсивності інвазії були - 9124 цисти. Кількість уражених бичків-пісочників метацеркаріями $C$. јејипа була $-15,9 \%$, а кількість паразитів, що було встановлено в одній рибині коливалась від 12 до 103 екземплярів. Показники ураження криптокотилюсами характеризують рівень забрудненості середовища існування риб біогенними елементами, що в свою чергу, створює комфортні умови для розвитку популяції молюсків роду Hydrobia. Останні, як відомо, є проміжними хазяями трематоди родини Heterophyidae, зокрема C. cancavum i $C$. јеjuna (рис. 1-2).

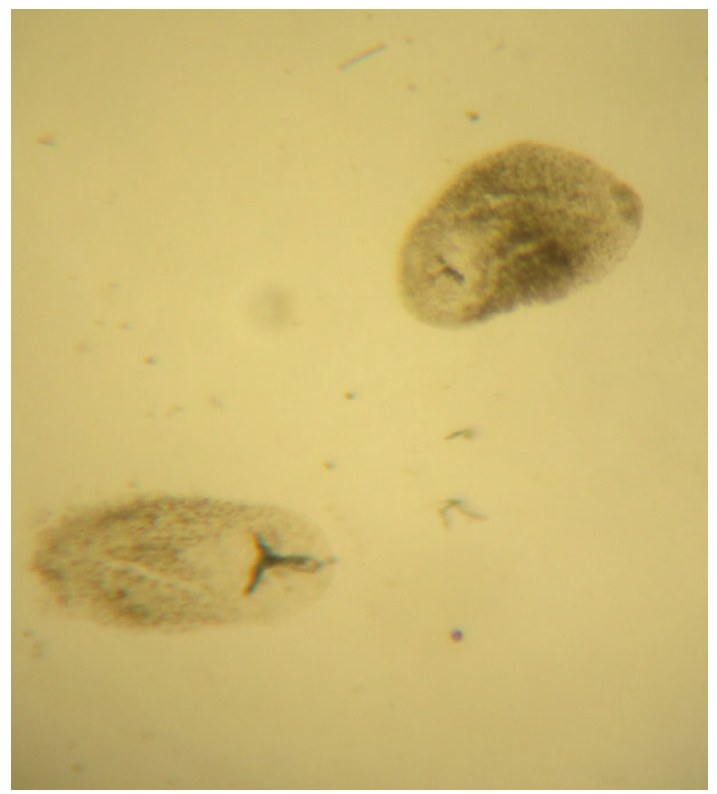

Рис. 2. Ексцистований метацеркарій $C$. сопсаvит (нативний препарат; збільш. х 80)

Дніпро-Бузького лиману. Також було встановлено на поверхні гепатопанкреаса білуваті цисти, які містили дегенерованих нематод та їхні фрагменти, що за анатомо-морфологічними ознаками були схожі на личинок нематод роду Raphidascaris. Але через значні зміни структури тіла виявлених паразитів дійти остаточного висновку щодо таксономічної належності останніх не видається можливим. Представником типових зоонозів, що були нами встановлені під час іхтіопатологічного дослідження, були личинки нематоди E. excisus. Даних паразитів встановлювали у 23,06\% досліджуваних бичків $N$. fluviatialis. Інтенсивність інвазії за еустронгілідозу була в межах 1-4 личинки паразита. Представником акантоцефальозів, якого встановлено при дослідженні бичків-пісочників, був скреблик - T. exiguus. Показник екстенсивності інвазії за даного паразитозу був на рівні 1,07\%, а інтенсивність інвазії - 1-2 екз. Сдиним представником паразитичних ракоподібних, що було встановлено нами за результатами іхтіопатологічного дослідження 
був E. nanus. Цим збудником було уражено $8,18 \%$ від загальної кількості досліджуваних бичків-пісочників.
Амплітуда інтенсивності інвазії за ергазильозу була 1-31 паразит (табл. 1).

\section{Таблиця 1}

Показники інвазування бичка-пісочика (Neogobius fluviatialis Pallas, 1814) збудниками паразитарних хвороб

\begin{tabular}{lccc}
\hline \multicolumn{1}{c}{ Назва збудників } & $\begin{array}{c}\text { Кількість інвазованих } \\
\text { екземплярів }\end{array}$ & $\begin{array}{c}\text { Екстенсивність інвазії } \\
\text { (ЕІ), \% }\end{array}$ & $\begin{array}{c}\text { Інтенсивність } \\
\text { інвазії (II), екз. }\end{array}$ \\
\hline Asymphylodora pontica Chernyshenko, 1949 & 12 & 2,58 & $4-12$ \\
Cryptocotyle concavum Creplin, 1825; met & 141 & 30,4 & $9-124$ \\
Cryptocotyle jejuna Nicoll, 1907; met & 74 & 15,9 & $12-103$ \\
Ligula pavlovski Dubinina,1959, larva & 1 & 1 iз 464 екз & 1 \\
Cucullanellus minutus Rudolphi, 1819 & 42 & 9,05 & $1-3$ \\
Eustrongylides excisus Jägerskiöld, 1909, larva & 107 & 23,06 & $1-4$ \\
Raphidascaris sp. larva & 13 & 2,8 & 1 \\
Telosentis exiguus (Linstow. 1901) & 5 & 1,07 & $1-2$ \\
Ergasilus nanus, Beneden, 1870 & 38 & 8,18 & $1-31$ \\
\hline
\end{tabular}

Дослідженнями бичка-кругляка було встановлено ураження трематодою $A$. pontica. Із загальної кількості досліджуваних бичків ураженими виявилися $10,2 \%$ риб. Амплітуда інтенсивності інвазії за даного паразитозу складала 5-36 трематод. Найбільший ступінь ураження серед усіх трематодозів був виявлений за криптокотильозу. Так при інвазуванні бичків зазначеного виду метацеркаріями C. concavum показник екстенсивності інвазії був на рівні $59,2 \%$, а інтенсивність інвазії була 94-211 цист. За ураження $N$. melanostomum метацеркаріями C. јејипа екстенсив-

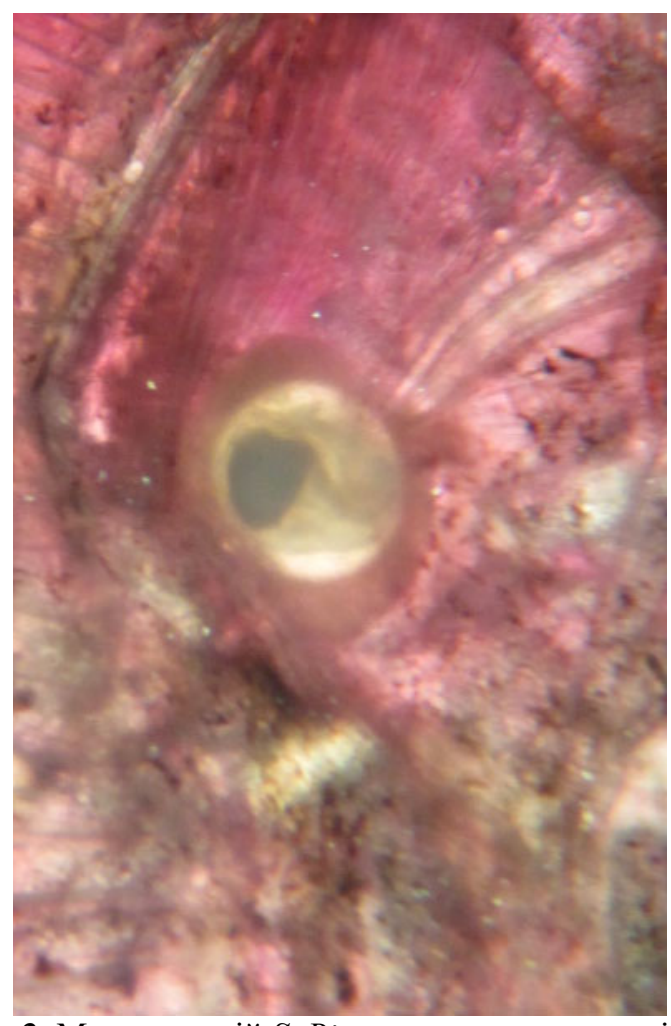

Рис. 3. Метацеркарій S. Bicoronatum на поверхні зябрової дуги бичка- кругляка (збільш. х 280)

Під час паразитологічного дослідження бичківкругляків виявляли збудника лігульозу, а саме плероцеркоїд L. pavlovski. Даний збудник був виявлений ність інвазії була $44,8 \%$, а показник амплітуди інтенсивності інвазії складав - 41-87 цист. Особливої уваги заслуговує ураження бичка-кругляка метацеркаріями трематоди $S$. bicoronatum. Метацеркарії даного збудника знаходили переважно на зябрових пелюстках та основах зябрових дуг. Личинки $S$. bicoronatum мали вигляд напівпрозорих округлих цист, в яких під час мікроскопії добре візуалізувався власне метацеркарій. Метацеркарій був скручений у цисті навпіл, вирізнявся добре виражений екскреторний міхур (рис. 3-4).

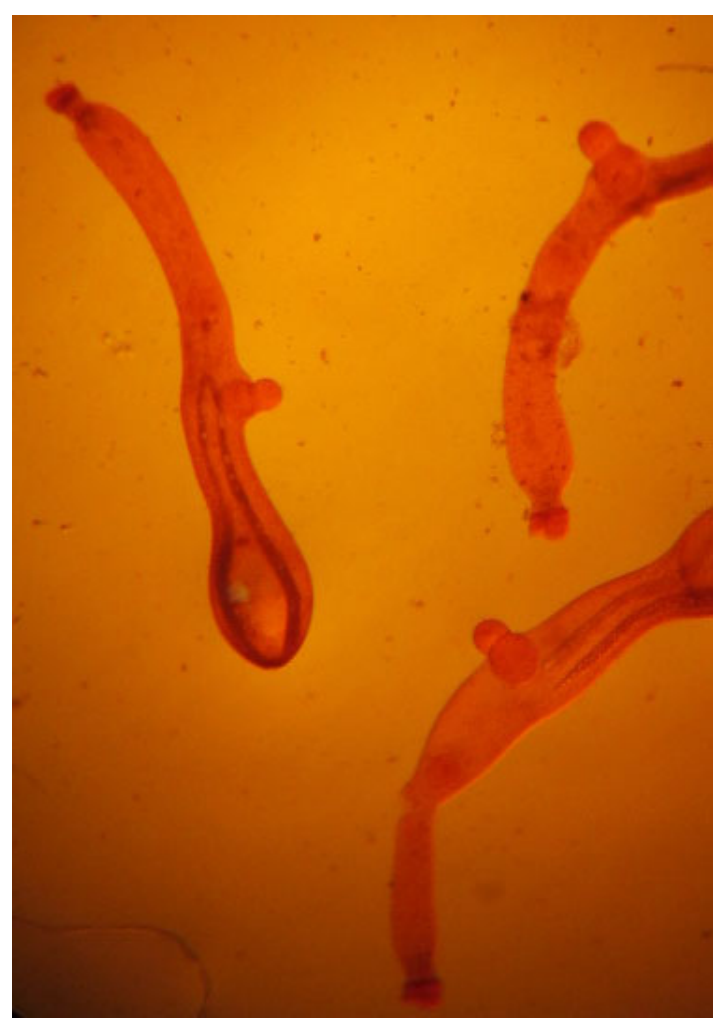

Рис. 4. Ексцистований метацеркарій S. bicoronatum (зафарб. квасцевиим карміном за Гренахером; збільш. х 280)

лише в одного бичка. Нематоду C. Minutus було встановлено у 16,3\% досліджуваних риб від усієї кількості 
бичків даного виду. Інтенсивність інвазії за ураження бичків даною нематодою була 1 - 6 паразитів (рис. 5).

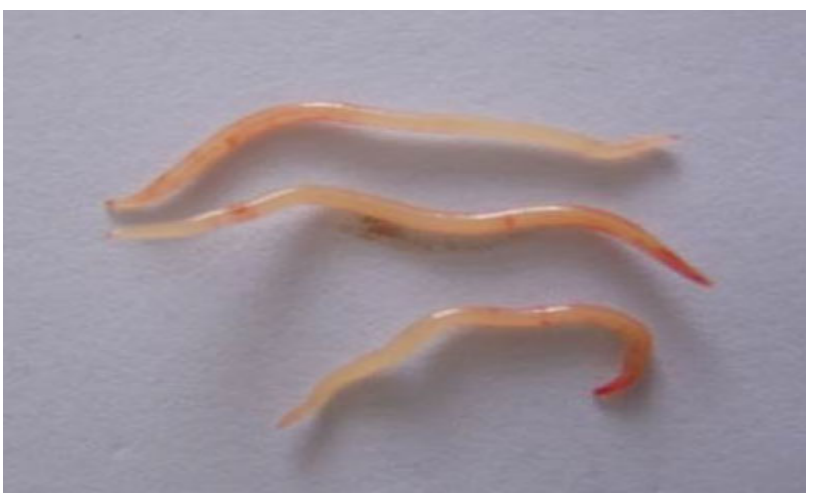

Рис. 5. Нематоди C. minutus від бичка-кругляка

Варто зазначити, що за даними Sulgostowska (1996) підвищення рівня ураженості даним збудником вказує на підвищений рівень органічного забруднення біогенними елементами.
Показники екстенсивності інвазії за ураження $N$. melanostomum збудником еустронгілідозу - нематодою E. excisus, складали 22,4\%. А інтенсивність інвазії була в межах 1-4 личинки паразита. Виявляли ураження двох екземплярів бичка-кругляка личинками нематоди Raphidascaris sp., що складало 4,08 \% від загальної кількості досліджуваних риб даної видової належності. Показник інтенсивності інвазії був на рівні 1-2 личонок нематоди.

Представником скребликів, виявленим під час наукових досліджень у бичка-кругляка, був - T. exiguus. Даного збудника як проміжного хазяїна використовує амфіпод Apherusa bispinosa. Бички інвазуються, споживаючи заражених личинками амфіпод. Так, показник екстенсивності інвазії за даного захворювання був на рівні 8,16\% від загальної кількості досліджуваних бичків. Амплітуда інтенсивності інвазії була в межах 1-2 акантоцефала. Дослідженням зябер виявляли паразитичного рачка E. nanus. Естенсивність інвазії за ергазильозу була на рівні 14,2\%, а амплітуда інтенсивності інвазії була в межах 2-8 паразита. (табл. 2).

\section{Таблиця 2}

Показники інвазування бичка-кругляка (Neogobius melanostomum Pallas, 1814) збудниками паразитарних хвороб

\begin{tabular}{lccc}
\hline \multicolumn{1}{c}{ Назва збудників } & Кількість інвазованих & Екстенсивність & Інтенсивність інвазії (II), екз. \\
\hline Asymphylodora pontica Chernyshenko, 1949 & 5 & 10,2 & $5-36$ \\
Cryptocotyle concavum Creplin, 1825; met & 29 & 59,2 & $94-211$ \\
Cryptocotyle jejuna Nicoll, 1907, met & 22 & 44,8 & $41-87$ \\
Stephanostomum bicoronatum Stossich, 1883 & 13 & 26,5 & $6-69$ \\
(Fuhrmann, 1928), larva & 1 & 1 iз 49 екз. & 1 \\
Ligula pavlovski Dubinina,1959, larva & 8 & 16,3 & $1-6$ \\
Cucullanellus minutus Rudolphi, 1819 & 11 & 22,4 & $1-4$ \\
Eustrongylides excisus, Jägerskiöld, 1909, larva & 2 & 4,08 & $1-2$ \\
Raphidascaris sp. larva & 4 & 8,16 & $1-2$ \\
Telosentis exiguus (Linstow. 1901) & 7 & 14,2 & $2-8$ \\
Ergasilus nanus, Beneden, 1870 & & \\
\hline
\end{tabular}

Іхтіопатологічними дослідженнями $M$. batrachocephalus було виявлено ураження збудником криптокотильозу. Екстенсивність інвазії за ураження метацекраріями C. concavum була $17 \%$, а амплітуда інтенсивності інвазії за даного паразитозу була в межах 1889 метацеркаріїв трематоди. Також було встановлено інвазування риби метацеркаріями $C$. јејипа 3 показником зараження 13,5\% від загальної кількості досліджуваних бичків-мартовиків. Інтенсивність інвазії була в межах 7-21 метацеркаріїв. На поверхні зябрових пелюсток і дуг було встановлено метацеркарії $S$. bicoronatum. Показник інвазування був на рівні $6,77 \%$, а амплітуда інтенсивності інвазії в межах 511 личинок паразита. За результатами клініколабораторних досліджень бичка-мартовика відмічали ураження нематодою C. minutus. Екстенсивність інвазії за цього нематодозу сягала $35,6 \%$ від загальної кількості досліджуваних бичків даної таксономічної належності, інтенсивність інвазії становила 1-3 гель- мінта. Типовим представником зоонозів, якого знаходили при дослідженні M. batrachocephalus, була нематода E. excisus. Інвазованими збудником еутронгілідозу виявилися 32,2\% бичків, яких піддавали паразитологічному дослідженню. Амплітуда інтенсивності інвазії була в межах 1-3 личинки нематоди. Цікавою знахідкою була нематода Contracaecum sp. (рис. 6-7).

Показники ураження цією нематодою були незначними $-5,08 \%$. У заражених бичків знаходили по одному екземпляру Contracaecum sp. Виявлення цих нематод у кишках бичків-мартовиків вказує на те, що вони ведуть також і хижацький спосіб життя, що проявляється в полюванні не лише на молюсків, а і на інших риб. За результатами лабораторних досліджень виявляли ураження бичків паразитичними рачками E. nanus. Екстенсивність інвазії за даного захворювання була $8,74 \%$, а інтенсивність інвазії складала $1-$ 15 паразитів (табл. 3). 


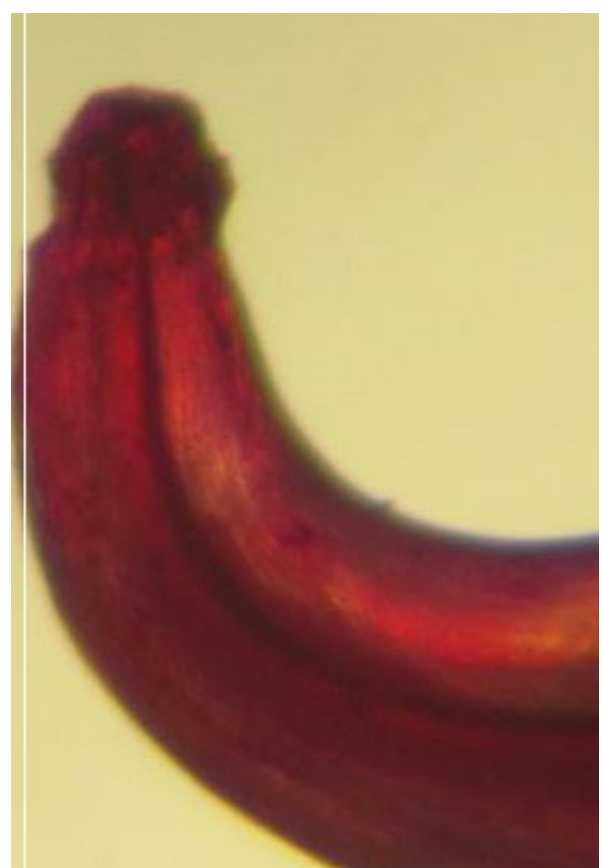

Рис. 6. Головний кінець нематоди Contracaecum sp. від бичка-мартовика (збільш. х 40)

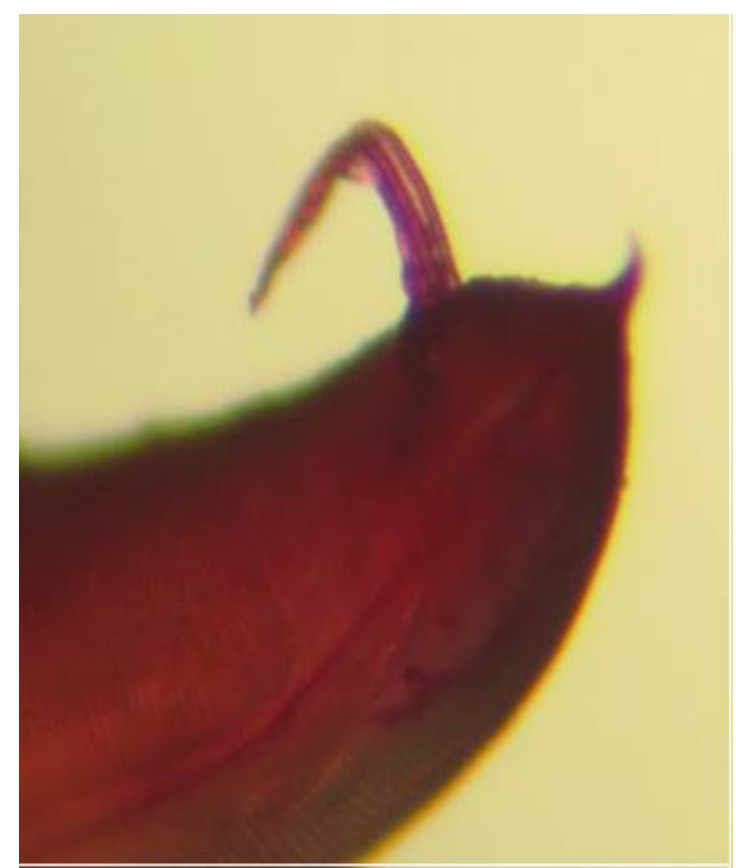

Рис. 7. Хвостовий кінець нематоди Contracaecum sp. від бичка-мартовика (збільш. х 40)

\section{Таблиця 3}

Показники інвазування бичка-мартовика (Mesogobius batrachocephalus Pallas, 1814) збудниками паразитарних хвороб

\begin{tabular}{|c|c|c|c|}
\hline Назва збудників & $\begin{array}{l}\text { Кількість інвазова- } \\
\text { них екземплярів }\end{array}$ & $\begin{array}{l}\text { Екстенсивність інвазії } \\
\text { (ЕI), \% }\end{array}$ & $\begin{array}{l}\text { Інтенсивність } \\
\text { інвазії (II), екз. }\end{array}$ \\
\hline Cryptocotyle concavum Creplin, 1825 ; met & 10 & 17 & $18-89$ \\
\hline Cryptocotyle jejuna Nicoll, 1907, met & 8 & 13,5 & $7-21$ \\
\hline $\begin{array}{l}\text { Stephanostomum bicoronatum Stossich, } 1883 \\
\text { (Fuhrmann, 1928), larva }\end{array}$ & 4 & 6,77 & $5-11$ \\
\hline Cucullanellus minutus Rudolphi, 1819 & 21 & 35,6 & $1-3$ \\
\hline Eustrongylides excisus, Jägerskiöld, 1909 larva & 19 & 32,2 & $1-3$ \\
\hline Contracaecum sp. & 3 & 5,08 & 1 \\
\hline Ergasilus nanus, Beneden, 1870 & 5 & 8,74 & $1-15$ \\
\hline
\end{tabular}

Аналізуючи отримані дані наукової роботи, варто зазначити, що переважна кількість представників паразитофауни риб родини Gobiidae представлена трематодами. Трематодози складають $52,2 \%$ від загальної кількості захворювань, які були встановленні під час іхтіопатологічного дослідження. Це свідчить про те, що бичкові риби є типовими хижаками - молюскофагами, що переважно i обумовлює їхній паразитологічний фон. Рівень ураження цестодами був незначним, лише - 0,37\%. За нашими науковими дослідженнями - показник ураження досліджуваних бичків нематодами складав 37,3\%. Інвазування акантоцефалами та паразитичними ракоподібними були на рівні 1,39 та 8,74\% відповідно (рис. 8).

Існування риб у водному середовищі нерозривно пов'язує цей факт із взаємодією з факторами абіотичної та біотичної природи, що в кінцевому підсумку, формує еволюційно побудовані паразито-хазяїнні відносини.
Мікстінвазії паразитарних хвороб бичкових риб природних водойм півдня України

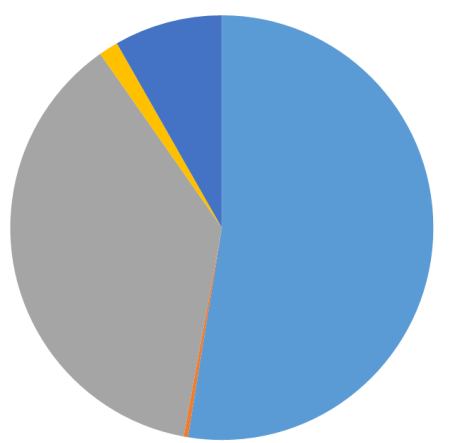

- Трематодози

- Цистодози

- Нематодози

- Акантоцефальози

- Крустаціози

Рис. 8. Рівень інвазованості бичкових риб

Життєдіяльність паразитів у біоценозі природних водойм забезпечується багатьма та різноманітними умовами, основною 3 яких $\epsilon$ наявність необхідного проміжного чи дефінітивного хазяїна, які б із збудником були в біоценотичному зв'язку. 
Більшість паразитів, що були встановлені під час іхтіопатологічних досліджень риб родини Gobiidae, $\epsilon$ типовими біогельмінтами. Як було зазначено вище, переважна кількість паразитарних захворювань викликана трематодами та нематодами - гельмінтами, які в процесі життєвого циклу як проміжних хазяїв використовують переважно молюсків, водних кільчатих червів та інших представників зообентосу (Sudarikov, 2016). Тому збільшення кількості нематодозів та трематодозів у загальній частці паразитофауни бичкових риб вказує на перенасичення акваторій ДніпроБузького лиману та Чорного моря органічними рештками та біогенними елементами.

Отже, варто зазначити, що гельмінтофауна риб родини Gobiidae $є$ досить різноманітною. Але особливої уваги заслуговують збудники криптокотильозу (C. concavum, C. јејuna) та еустронгілідозу (E. excisus) оскільки вони $є$ типовими представниками заоонозів та становлять загрозу здоров'ю людей і тварин. Заслуговує уваги той факт, що станом на сьогодні жодний нормативно-правовий акт не відображає послідовності дій при виявленні вказаних паразитів у промисловій рибі. Враховуючи відсоток ураження бичків збудниками криптокотильозу та еустронгілідозу і поширення даних захворювань, це питання потребує якнайшвидшого вирішення.

\section{Висновки}

1. Досліджено сумісне паразитування збудника криптокотильозу з іншими паразитами бичкових риб. Встановлено, що риба родини Gobiidae найбільше уражена представниками класу трематод та нематод: 52,2 та 37,3\% відповідно. Найменшою групою паразитів, що уражає бичків, є цестодози - 0,37\%.

2. Виявлено, що N. fluviatialis найчастіше уражається збудником криптокотильозу в асоціації із E. excisus (EI - 23,06\%, II - 1-4 личинки нематод), C. minutus (EI - 9,05\%, II - 1-3 екз.) та E. nanus (EI $8,18 \%$, II - 1-31 паразит).

3. У $N$. melanostomum асоціативне протікання криптокотильозу найчастіше представлене сумісним паразитуванням $S$. bicoronatum (EI - 26,5\%, II - 6-69 метацеркаріїв), E. excisus (EI - 22,4\%, II - 4-4 личинки), C. minutus (ЕI - 16,3\%, II $-1-6$ нематод), E. nanus (EI - 14,2\%, II - 2-8 паразитичних рачки).

4. Мікстінвазії у M. batrachocephalus за ураження метацеркаріями трематоди родини Heterophyidae 3 іншими паразитами мали найбільші значення при одночасному інвазуванні з E. excisus (EI - 32,2\%, II 1-3 паразита), C. minutus (EI - 35,6\%, II - 1-3 нематоди), E. nanus (ЕI - 8,74\%, II - 1-15 рачків).

\section{References}

Bikhovskaya-Pavlovskaya, I.E. (1986). Parasites of fish: Study Guide. Nauka, Leningrad, 1985. 1- 121. Britton G. Biochemistry of natural pigments. Moscow. Publisher: Mir.

Dogel', V.A. (1962). Global parasitology. I-vo: Leningradskogo universiteta.

Gardner, S.L., \& Thew, P.T. (2006). Redescription of Cryptocotyle thapari McIntosh, 1953 (Trematoda: Heterophyidae), in the river Otter Luttra longicaudis from Bolivia. Comparative Parasitoligy, 73(1), 20-23. doi: 10.1654/0001.1.

Gibson, D.I., Jones, A., \& Bray, A. (2002). Keys to the Trematoda. Vol. 1. Wallingford: CABI Publ.

Gibson, D.I., Jones, A., \& Bray, A. (2005). Keys to the Trematoda. Vol. 2. Wallingford: CABI Publ.

Gibson, D.I., Jones, A., Bray, A. (2008). Keys to the Trematoda. Vol. 3. Wallingford: CABI Publ.

Malek, M. (2004). Parasites as discrimination Keys in two sympatric species of gobies. European Assotiatin of fish Pathologist, 24(4), 173-179. https://eafp.org/download/ 2004-Volume24/Issue\%204/24 173.pdf.

Martynenko, I.M. (2012). On the finding of Cryptocotyle jejuna (Nicoll, 1907) Ransom, 1920 in the Kerch Strait. Reports of the conference of young researchers zoologists. Institute of Zoology NAS of Ukraine. Kiev.

Martynenko, I.M. (2016). About morphological differentiation of species of the genus Cryptocotyle. Modern problems in theory and Marine Parasitology. Sevastopol.

Moshu, A. (2014). Helminths of fish ponds between the rivers Dniester and Prut, potentially dangerous to human health. Kishineu: Eco-Tiras, 1-88.

Rolbiecki, L. (2006). Parasites of the round goby Neogobius melanostomus (Pallas, 1811), an invasive species in the Polish fauna of the Vistula Lagoon ecosystem. Oceanologia, 48(4), 545-561. http://water.iopan.gda.pl/oceanologia/484rolbi.pdf.

Sudarikov, V.J., Lomakin, V.V., Atajev, A.M., \& Semenova, N.N. (2006). Metacercaria of trematodaes, parasites of fish in the Caspian Sea and the Volga River Delta. Nauka, Moskow, 1-183.

Sulgostowska, T., \& Styczyn'ska-Jurewicz, E. (1996). Internal helminth parasites of the flounder, Platichthys flesus L., as tags of pollution in the Gulf of Gdan'sk, Southern Baltic Sea, Crangon: Proc. 2nd Intern. Estuary Symp. (Gdan'sk, October 18-22, 1993). Gdynia, 1, 211-220.

Thieltges, D.W., Krakau, M., \& Andresen, H. (2006). Makroparasite community in molluses of a tidal basin in the Wadden Sea. Helgol. Mar. Res, 60, 307-316. doi: 10.1007/s10152-006-0046-3. 